\title{
The Role of International Law in Vaccinating Against COVID-19: Appraising the COVAX Initiative
}

\author{
Armin von Bogdandy \\ Director, Max Planck Institute for Comparative Public Law and Interna- \\ tional Law, Heidelberg, Germany \\ bogdandy@mpil.de \\ Pedro A. Villarreal \\ Senior Research Fellow, Max Planck Institute for Comparative Public Law \\ and International Law, Heidelberg, Germany \\ villarreal@mpil.de*
}

$\begin{array}{lr}\text { Abstract } & 89\end{array}$

$\begin{array}{ll}\text { Keywords } & 90\end{array}$

I. The Distributive Dilemma of a COVID-19 Vaccine 90

II. The Context of COVAX $\quad 91$

1. Patent Law 92

2. Legal Instruments of Vaccine Nationalism 95

3. Considerations of Global Solidarity 99

III. The Set-up and Operation of COVAX 101

1. The Institutional Setup $\quad 102$

2. The Structure of Commitments 106

3. The Allocation of Vaccines 107

$\begin{array}{lr}\text { IV. COVAX and Human Rights } & 109\end{array}$

1. The Domestic Preference in the International Right to Health 109

2. The No Harm Principle 111

3. The Duty of International Assistance 113

V. Conclusion: COVAX as a Template for Sustainable Solidarity 116

\begin{abstract}
Finally, there are approved vaccines against COVID-19, but they will be certainly scarce at first. As a result, vaccine nationalism is rampant. However,

* The authors would like to especially thank Anne Peters, Michael Ioannidis, Theodor Shulman, Martin Jarrett, Matthias Goldmann, Janne Mende, as well as all members of the Institute's Tuesday Round (Dienstagsrunde) for their valuable input to earlier versions of this text. We are also grateful to the two anonymous peer reviewers for insightful suggestions on how to improve the article.
\end{abstract}


for considerations of self-interest, solidarity as well as of international law, national governments should also cater for the health of other countries' populations. This article presents the main legal instruments of vaccine nationalism as well as the COVAX Initiative as an instrument for a fairer global distribution of the life-saving medicine. An analysis of the international right to health shows the normative underpinnings of COVAX and the promise it holds for sustainable solidarity.

\section{Keywords}

COVID-19 vaccine - WHO - Gavi - COVAX - vaccine nationalism international right to health - sustainable solidarity

\section{The Distributive Dilemma of a COVID-19 Vaccine}

As the number of COVID-19 cases faces constant ups and downs, countries around the world witness a cycle of implementation-lifting-reimplementation of restrictive public health measures to contain the spread of the root cause, the SARS-CoV-2 virus. Such measures put affected populations under a heavy strain. There is a deep yearning to return to a pre-pandemic state of affairs in terms of liberties and economics. ${ }^{1}$ For that, safe and effective vaccines are the best path. If and when properly distributed, they could put an end to most, if not all restrictions. Therefore, demand for such vaccines is literally global in nature, and will initially exceed supply:2 Manufacturing capacities will not be enough to furnish sufficient doses to the entire globe at the same time, at least during the initial stages.

Accordingly, authorities all over the world face a distributive dilemma, both within and across countries. This article deals with the latter. On the one hand, any government is subject to huge pressure to quickly procure a safe and effective vaccine for the largest possible number of its country's population. As a result, vaccine nationalism is rampant. ${ }^{3}$ On the other hand,

1 Covid-19: Normal Life Back Next Winter, Says Vaccine Creator, BBC, 15 November 2020, <https://www.bbc.com>. Lawrence Gostin, Safura Karim and Benjamin Mason Meier, 'Facilitating Access to a COVID-19 Vaccine through Global Health Law', Journal of Law, Medicine \& Ethics 48 (2020), 622-626.

2 Alan Sykes, 'Short Supply Conditions and the Law of International Trade: Economic Lessons from the Pandemic', AJIL 114 (2020), 647.

3 WHO Director-General's opening remarks at the media briefing on COVID-19, 18 August 2020, <https://www.who.int $>$. 
the pandemic is a global phenomenon. For considerations of effectiveness, solidarity as well as of international law obligations, national governments should also cater for the health of other countries' populations.

Indeed, in 2015 all UN Members pledged in the United Nations' Sustainable Development Goals to "Ensure healthy lives and promote well-being for all at all ages". ${ }^{4}$ Along that line, the WHO's main organ, the World Health Assembly - which comprises representatives of all Member States - approved on 19 May 2020 a resolution declaring immunization against COVID-19 a "global public good". ${ }^{5}$ The COVAX (Covid Vaccination) Initiative, spearheaded by the WHO and the object of this article, is so far the main international framework to realise this good.

The article presents, first, some important elements of the context of COVAX, in particular the international law of patent protection, the possible instruments of vaccine nationalism as well as the considerations for global solidarity. The second section describes COVAX, both its complex institutional set-up as well as its underlying legal agreements and distributive mechanism. The third section deepens the understanding of COVAX by explaining its underpinning in human rights. We offer conclusions, finally, in the fourth section.

\section{The Context of COVAX}

Although antimicrobial and antiviral medicines in general can help against communicable diseases, ${ }^{6}$ vaccines are the focus of the current analysis. ${ }^{7}$ They have been a watershed for global health. Broadly speaking, they allow inoculated persons to build immune responses for specific diseases without having to suffer an actual infection - the consequences of which may be fatal. German Nobel prize winner Paul Ehrlich coined the term "magic bullet" (Zauberkugel) in 1900 to refer to such remedies. ${ }^{8}$

Thanks to the growing list of "magic bullets", as well as other technological advances in medical science, the 20th Century witnessed tremendous

4 Goal 3 of the United Nations Sustainable Development Goals, 2030 Agenda for Sustainable Development, <https://sdgs.un.org>.

5 WHO, COVID-19 response. World Health Assembly Resolution WHA 73.1 of 19 May 2020, para. 6, <https://bit.ly/34npwrp>.

6 The Food and Drug Administration of the United States of America has approved an antiviral medication, Remdesivir, though only for use in a hospital or other healthcare settings providing acute care. $<$ https://www.fda.gov>.

7 Robert Friis, Epidemiology 101 (Sudbury: Jones and Bartlett Publishers, 2010), 138.

8 Robert Schwartz, 'Paul Ehrlich's Magic Bullets', The New England Journal of Medicine 350 (2004), 1079-1080. 
achievements in the field of health. Communicable diseases ceased to be the main global cause of death. ${ }^{9}$ But they still linger in countries that, mostly due to reasons of economic development and insufficient investment in healthcare systems, lack proper access to medical technologies. Some public health experts label communicable diseases as "diseases of underdevelopment", 10 although this label is certainly contested. ${ }^{11}$ The purpose of COVAX is that COVID-19 does not turn into such a phenomenon.

A first issue COVAX has to face is that COVID-19 vaccines, as do other new pharmaceutical products, will mostly emerge from high income countries that have the resources to conduct the necessary research. ${ }^{12}$ Any mechanism of global distribution must consider that the governments of those countries, but also their pharmaceutical corporations, will be in the driver's seat. ${ }^{13}$ Access for middle and lower income countries will be hampered if there is no corrective action to take into account the mechanisms of control that both companies and governments yield. Of these mechanisms, patent law and export restrictions stand out as two examples of control through law.

\section{Patent Law}

One legal regime that determines access to medicines to a large extent is patent law. New medicines are usually protected by patents, which can prevent lower and middle income countries from producing the same vaccines. In very simplified terms, a patent grants an exclusive right to innovators, thereby placing them in a situation of monopoly. ${ }^{14}$ Patent rights are granted by a national or regional authority. Once issued, third parties wishing to make, use, offer for sale, sell or import a patented product cannot do so in jurisdictions covered by a patent unless they receive authorisation from the patent-holder. Such authorisation usually comes with a price tag, as pharmaceutical companies are set up to make a profit. That price tag is often a

9 See the trend in Abdel Omran, 'The Epidemiologic Transition: A Theory of the Epidemiology of Population Change', The Milbank Quarterly 83 (2005), 731-757 (739).

10 Friis (n. 7), 138.

11 Peter Hotez, 'The Disease Next Door', Foreign Policy, 25 March 2013, <https://foreign policy.com>.

12 The exact amounts are a highly contested matter, in particular because the full costs are deemed "trade secrets". Veronika Wirtz et al., 'Essential medicines for universal health coverage', The Lancet 389 (2017) 403-476 (454).

13 Stuart Schweitzer and Z. John Lu, Pharmacentical Economics and Policy. Perspectives, Promises, and Problems, 3rd edn (Oxford: Oxford University Press, 2018), 135-136.

14 For an overview, see Holger Hestermeyer, Human Rights and the WTO. The Case of Patents and Access to Medicines (Oxford: Oxford University Press, 2007). 
problem for healthcare systems in general, ${ }^{15}$ where having access to those medicines without having to incur in very onerous or even catastrophic expenditure is a matter of public interest. ${ }^{16}$ There are certainly exceptions to this model. For instance, companies such as AstraZeneca have agreed to produce and distribute the vaccine against COVID-19 at a comparatively much lower cost. ${ }^{17}$

International law extends patent protection globally. The core instrument is the Agreement on Trade-Related Aspects of Intellectual Property Rights (TRIPS), as one of the agreements covered under the World Trade Organization (WTO) Marrakech Accords. ${ }^{18}$ Broadly speaking, it emerged as the result of both a stalemate in negotiating new rules under the auspices of the World Intellectual Property Organization, as well as developed countries' desire to link the protection of intellectual property rights to trade concessions under the General Agreement on Tariffs and Trade (GATT) during the Uruguay Round leading to the WTO. ${ }^{19}$ Through Art. 1 TRIPS Agreement, the minimum standards for patent protection are extended to all WTO Members.

Of course, patents are not absolute rights under domestic and international law. The TRIPS Agreement recognises there may be situations where the lack of authorisation for third parties is unacceptable. Thus, art. 31 TRIPS Agreement allows national regulatory authorities to authorise the use of an innovation protected by patent even without the authorisation of the patentholder. $^{20}$

However, this tool is not a Zauberkugel for global health. First, compensation is still to be paid, according to Art. 31(h) TRIPS Agreement. Moreover, Art. 31(f) TRIPS Agreement affirms that the compulsory license mechanism should be used "predominantly" for supplying the domestic market. This has

15 Richard Elliott, 'Managing the Market for Medicines Access: Realizing the Right to Health by Facilitating Compulsory Licensing of Pharmaceuticals - A Case Study of Legislation and the Need for Reform' in: Lisa Forman and Jillian Kohler (eds), Access to Medicines as a Human Right. Implications for Pharmaceutical Industry Responsibility (Toronto: University of Toronto Press, 2012), 151-178 (153-155).

16 Reto Hilty, 'Legal Remedies Against Abuse, Misuse, and Other Forms of Inappropriate Conduct of IP Right Holders', in: Reto Hilty and Kung-Chung Liu (eds), Compulsory Licensing. Practical Experiences and Ways Forward (Berlin-Heidelberg: Springer 2015), 377-396 (378); Adam Wagstaff et al., 'Progress on Catastrophic Health Spending in 133 Countries: a Retrospective Observational Study', The Lancet Global Health 6 (2018) E-169-E-179.

17 However, this is not a fully consistent practice. 'South Africa paying more than double EU price for Oxford vaccine', The Guardian, 22 January 2021, <https://www.theguardian.com>.

$18 \mathrm{WHO} / \mathrm{WTO} /$ World Intellectual Property Organization, Promoting Access to Medical Technologies and Innovation (2nd edn, Geneva, 2020), 65, Box 2.6.

19 Hestermeyer (n. 14), 44-48.

20 Aditi Bagchi, 'Compulsory Licensing and the Duty of Good Faith in TRIPS', Stanford L. Rev. 55 (2003), 1529-1556 (1531). 
represented an obstacle to countries that, due to a lack of facilities, cannot produce life-saving medicines. The Doha Declaration on TRIPS and public health, which was adopted at the Ministerial Conference of the WTO in the year 2000, aimed to fix this deficiency. ${ }^{21}$ Its paragraph 4 states, "the TRIPS Agreement does not and should not prevent members from taking measures to protect public health [...] [but rather] the Agreement can and should be interpreted and implemented in a manner supportive of WTO members' right to protect public health and, in particular, to promote access to medicines for all".

In 2017, Art. 31bis TRIPS expanded the international system of compulsory licences. It permits taking into account the needs of those states with "insufficient or no manufacturing capacity". ${ }^{22}$ The provision allows for exporting pharmaceutical products to "eligible importing Member(s)", i. e., those classified as "developing or least developed".

Art. 31bis TRIPS represented a breakthrough in WTO law. ${ }^{23}$ Yet the underlying conditions of unequal pharmaceutical capacities across states have persisted. Aside from notable exceptions such as Brazil, India and Russia, ${ }^{24}$ numerous lower- and middle-income countries have been unable to build their own self-standing pharmaceutical industries. ${ }^{25}$ As compulsory licenses are granted to individual producers and not in the abstract, the lack of a manufacturer able or willing to supply the medicine means the only alternative is importing the medicine from a foreign producer. But this legal mechanism can still be cumbersome in light of the required "adequate remuneration" to the patent-holder under the second paragraph of Art. 31bis TRIPS, a matter which may also be subjected to national judicial review, thus potentially leading to protracted and expensive litigation. ${ }^{26}$ Besides adopting these regulatory requirements, public and private healthcare providers must negotiate the actual terms of the licenses with potential manufacturers, who must be actively willing to provide a particular medicine. ${ }^{27}$

21 Suerie Moon and Wolfgang Hein, Informal Norms in Global Governance. Human Rights, Intellectual Property Rules and Access to Medicines (Farnham: Ashgate, 2013), 188-190.

22 Terms used in Article 31, TRIPS Agreement.

23 Hilty (n. 16), 378.

24 Known as "pharmerging countries" due to their ever-growing national pharmaceutical sector. Ravinder Gabble and Jillian Kohler, 'To Patent or not to Patent? The Case of Novartis' Cancer Drug Glivec in India', Globalization and Health 10 (2014), 1-6.

25 'WTO IP rules amended to ease poor countries' access to affordable medicines', WTO Nerws Items, 23 January 2017, <https://www.wto.org>.

26 Anthony Taubman, 'Rethinking TRIPS: “Adequate Remuneration” for Non-voluntary Patent Licensing', JIEL 11 (2005), 927-970 (947-950).

27 Frederick Abbott and Jerome Reichman, 'Facilitating Access to Cross-Border Supplies of Patented Pharmaceuticals: The Case of the COVID-19 Pandemic', JIEL 23 (2020), 535-561 (552-554). 
In sum, even if the compulsory licensing system in the TRIPS Agreement allows overcoming patent protection, it certainly does not by itself contribute towards a fair and equitable global distribution of COVID-19 vaccines, particularly in lower-income countries. They are mostly dependent on importing vaccines from pharmaceutical companies located in foreign countries. ${ }^{28}$ The resulting transactions between states and foreign pharmaceutical providers must be in compliance with the rules of international trade law, particularly of intellectual property. If a patent is at stake, both the exporting (i. e. where a pharmaceutical manufacturer is located) and the importing states must have an authorisation to manufacture and distribute the vaccine accordingly, either through voluntary or compulsory licensing.

At the WTO Trips Council, several countries have proposed a waiver of international intellectual property rights under TRIPS for confronting the COVID-19 pandemic. ${ }^{29}$ This would allow any pharmaceutical manufacturer regardless of location to produce and distribute vaccines against COVID-19, subject to authorisation by regulatory agencies certifying safety and effectiveness. But so far, the proposal of a general waiver has been unsuccessful due to the opposition by higher-income countries. ${ }^{30}$ Nevertheless, COVAX pays heed to intellectual property rights by signing agreements with, and thus obtaining voluntary licensing from pharmaceutical companies at the forefront of COVID-19 vaccine research and development, i. e. those likely to become patent-holders. ${ }^{31}$ This ensures that the eventual vaccine distribution through COVAX takes place in conformity with existing TRIPS rules.

\section{Legal Instruments of Vaccine Nationalism}

COVAX is beneficial in another regard as well. Every state has major incentives to use its financial and regulatory capacities to secure as many doses as fast as possible - at the expense of countries that lack comparable means. If there is no corrective to the logic of the market, states can outspend

28 As already recognised by the World Health Organization's Commission on Intellectual Property Rights, Innovation and Public Health, Public Health, Innovation and Intellectual Property Rights (Geneva, 2006), 21.

29 WTO, Waiver from Certain Provisions of the TRIPS Agreement for the Prevention, Containment and Treatment of COVID-19. Communication from India and South Africa, Council for Trade-Related Aspects of Intellectual Property Rights, IP/C/W/669, 2 October 2020.

30 Emma Farge and Stephanie Nebehay, 'WTO delays decision on waiver on COVID-19 drug, vaccine rights', Reuters, 10 December 2020, <https://www.reuters.com>.

31 COVAX Facility, Terms and Conditions for Self-Financing Participants, Term 12, $<$ https://www.gavi.org>. 
each other in an attempt to procure the vaccines for themselves and use them to immunise their population as soon as possible. ${ }^{32}$

One important instrument for securing such access lies in the so-called Advance Purchase Agreements (APAs). Basically, these are contracts signed between parties in which one of them, the supplier or provider, commits to provide a certain amount of the medical product to the purchaser, often a public entity or healthcare provider, at a specific point in the future. ${ }^{33}$ The contractual terms vary, ${ }^{34}$ but an APA guarantees access mostly in exchange for either an upfront payment, a price per dose higher than that charged to other interested parties, or financial support during the development process. Thus, the supplier or provider gives a time-based preference to those with whom it has entered into these contracts. Through such an instrument, many higher income countries can reserve access that is likely to leave the population of lower income countries later in the supply chain. ${ }^{35}$

As their activation depends on future developments, APAs are set up against a background of risk. In the case of the vaccine against COVID-19, since from the outset there were multiple candidates striving towards regulatory authorisation, it could not be known which ones would succeed. ${ }^{36}$ Therefore, depending on their formulation, multiple APAs may be signed with a diverse set of counterparties in order to increase the chances of obtaining the successful ones.

APAs are not the only legal instrument of vaccine nationalism. The pandemic has been invoked as a justification for national preferential treatment in multiple regimes of international law, including international trade law. ${ }^{37}$ Measures such as export restrictions or outright prohibitions ${ }^{38}$ stymie access by other interested countries. This occurred through documented restrictions on medical supplies in the initial stages of the pandemic. ${ }^{39}$ States and the

32 David P. Fidler, 'Vaccine Nationalism's Politics', Science 369 (2020), 749.

33 See the definition also in Alexandra Phelan, Mark Eccleston-Turner, Michelle Rourke, Allan Maleche and Chenguang Wang, 'Legal Agreements: Barriers and Enablers to Global Equitable COVID-19 Vaccine Access', The Lancet 396 (2020), 800.

34 For a brief overview, <https://www.dw.com>.

35 Mark Turner, 'Vaccine Procurement During an Influenza Pandemic and the Role of Advance Purchase Agreements: Lessons from 2009-H1N1', Global Public Health 11 (2016), 322-335.

36 Ernst Berndt and John Hurvitz, 'Vaccine Advance-Purchase Agreements for Low-Income Countries: Practical Issues', Health Affairs 24 (2005), 653-665 (658).

37 Julian Arato, Kathleen Claussen and J. Benton Heath, 'The Perils of Pandemic Exceptionalism', AJIL 114 (2020), 627-636 (636).

38 Sykes (n. 2), 656.

39 See the official list of COVID-19 related trade measures as of 1 February 2020 in $<$ https://www.wto.org>. For instance, on March 2020, Germany decided to impose an export prohibition on medical masks, useful against COVID-19. The prohibition was lifted after only one week. See $<$ https://www2.deloitte.com>. 
European Union have either conducted or are hinting at deploying export restrictions $s^{40}$ to ensure that medical products remain within their national healthcare systems. ${ }^{41}$ This comes at the expense of other countries that might be in need of the same products but either do not have a sufficient capacity to manufacture them or are experiencing, due to the needs generated by the pandemic, a particularly dire scarcity of medical products. It is hard to overstate the temptation for states to keep vaccines against COVID-19 manufactured in their own territories for themselves. ${ }^{42}$

GATT Art. XI:1 generally prohibits such restrictions. But GATT Article $\mathrm{XI}: 2(\mathrm{a})$ allows for temporary export prohibitions or restrictions for the purpose of "tackling critical shortages of foodstuffs or other products essential to the exporting [country]". It can be expected that a potential vaccine against COVID-19 will fall under any possible definition of an "essential product" ${ }^{43}$ Moreover, Art. XX(b) GATT would also allow for these trade restrictions, but only if they are duly notified to the $\mathrm{WTO}^{44}$ and if they can be justified as "necessary" to protect life and health. ${ }^{45}$ In short, it should not be too difficult to make the case for both of these exceptions during the current pandemic. ${ }^{46}$

In China - Raw Materials, the WTO Appellate Body interpreted the terms "temporary", "critical shortage" and "essential product", used in Art. XI(2) GATT, narrowly, mostly by resorting to dictionary definitions. ${ }^{47}$ As regards measures "applied temporarily", it established that restrictive measures are aimed at addressing a "passing need". This means they need to be "of limited duration and not indefinite", ${ }^{4}$ although they do not require "a time-limit fixed in advance" ${ }^{49}$ In the context of prohibiting the export of vaccines

40 Commission Implementing Regulation 2021/111/EU, 29 January 2021, <https://eurlex.europa.eu>.

41 Timothy Meyer, 'Trade Law and Supply Chain Regulation in a Post-COVID-19 World', AJIL 114 (2020), 638.

42 Adam Kamradt-Scott, "Why "Vaccine Nationalism" Could Doom Plan for Global Access to a COVID-19 Vaccine', The Conversation, 7 September 2020, <https://theconversation. com>. 'EU First as Italy Blocks Exports of 250,000 COVID Vaccines to Australia', Euronews, 5 March 2021, <https://www.euronews.com>.

43 Sykes (n. 2), 653-654.

44 In the case of export quotas, see the procedural requirements enshrined in WTO, Decision on Notification Procedures for Quantitative Restrictions, G/L/59/Rev.1, adopted by the Council for Trade in Goods on 22 June 2012.

45 Gabrielle Marceau, 'WTO and Export Restrictions', J. W. T. 50 (2016), 563-86 (571-572).

46 Arato, Claussen and Heath (n. 37), 636.

47 All of these linguistic definitions are taken from the Oxford English Dictionary. WTO, Appellate Body, China - Measures Related to the Exportation of Various Raw Materials, Report of 30 January 2012 (adopted on 22 February 2012), WT/DS394/AB/R, paras 319-327.

48 WTO, Appellate Body, China - Various Raw Materials (n. 47), para. 330.

49 WTO, Appellate Body, China - Various Raw Materials (n. 47), para. 331. 
against COVID-19, these limitations should be rather easy to fulfil. The same is true for the requirement that there be a "critical shortage", that is, a "deficiency in quantity" of a vital resource. ${ }^{50}$

Shortage, however, is to be understood on the basis of an empirical assessment. According to WTO case law, states aiming at justifying export restrictions of a product have the burden of proof in demonstrating that they are, indeed, in shortage. ${ }^{51}$ Given that there is a simultaneous urgent need for the vaccine against COVID-19 elsewhere, the understanding of shortage could be limited to securing sufficient doses for a country's own population. Accordingly, stockpiling vaccines against COVID-19 would not be justified on the basis of GATT/WTO law. As seen below, more expansive interpretations could also be possible, where a country is deemed to have sufficient doses once it reaches a certain threshold of its population. This would be more difficult, as it would require a consensus within the scientific i.e. medical and public health communities regarding the health benefits of such a threshold.

GATT Article XX(b) could also justify export prohibitions or restrictions to protect human health. The devastating dimensions of the COVID-19 pandemic could be invoked as a blanket justification for any restriction on trade with regard to vaccines.52 However, a similar reasoning to the one applicable for GATT Article XI:2 could be deployed when interpreting the term "necessary" in Article XX(b). A state adopting a measure under this exception is obliged to prove why a specific measure is "necessary" in order to attain the goal of protecting human health. ${ }^{53}$ The question would be whether export restrictions of vaccines would actually be conducive towards higher rates of immunity against COVID-19 in a given population. Here, the burden of proof is on the state applying the measure.

The goal of such interpretation of international trade law is to counteract stockpiling of essential medicines in a moment of dire global need. It is supported both by the Goal 3 of the United Nations Sustainable Development Goals as well as the World Health Assembly Resolution of 19 May $2020.5^{54}$ Therefore, international trade law provides some limits on vaccine

50 WTO, Appellate Body, China-Various Raw Materials (n. 47), para. 325.

51 This analysis would correspond to WTO Panels, since their discretion in undertaking such factual assessments has been reaffirmed by the Appellate Body. WTO, Panel Report, China - Measures Related to the Exportation of Various Raw Materials, Report of 5 July 2011, para. 7.351; upheld in WTO, Appellate Body, China - Raw Materials (n. 47), paras 341-344.

52 Arato, Claussen and Heath (n. 37), 629.

53 Peter-Tobias Stoll and Lutz Strack, 'Article XX lit. b. GATT' in: Rüdiger Wolfrum, Peter-Tobias Stoll and Holger Hestermeyer (eds), WTO - Trade in Goods (Leiden/Boston: Martinus Nijhoff Publishers, 2011), 497-524 (513).

54 WHO, COVID-19 response (n. 5). 
nationalism, however only on its crudest form. For this safeguard to work, moreover, information is needed on the exact quantities of the vaccine that states secure for themselves. As seen below, such an enterprise encounters major obstacles due to issues of transparency. Not least, imposing such limits would require tedious international litigation, which certainly fails the urgent needs of the afflicted populations. An agreed multilateral mechanism is far more conducive to this end, and the shadow cast by the prospect of illegality under WTO law in case of not adhering to it might support such a proposal. But there are far more important reasons to support an initiative like COVAX.

\section{Considerations of Global Solidarity}

The pressure on states to serve their population first is so strong that they might ruthlessly disregard the health of other peoples; this is what we call vaccine nationalism. Indeed, there are important normative arguments in favour of taking into account the interests of other countries and their populations. ${ }^{55}$ From a legal perspective, states should not hinder the exercise of the right to health in other territories. ${ }^{56}$ Moreover, from a factual perspective, unmitigated vaccine nationalism is likely to be self-defeating, for two salient reasons.

First, as the COVID-19 pandemic is literally a global concern, it does not make much sense for one country to constitute itself as a disease-free island amidst a sea of infection. If other countries continue to suffer under the pandemic, the global economy will remain in recession, countries might become more unstable, the migration pressure might increase, and international travel will remain hampered. All these externalities would afflict the disease-free island as well, as exemplified by the slogan "no one is safe until everyone is". ${ }^{57}$ Second, vaccine nationalism is also self-defeating because it hampers multilateral cooperation. Since the current supply chain of pharmaceutical production is global, it requires the participation of multiple states..$^{58}$

55 Eyal Benvenisti, 'Sovereigns as Trustees of Humanity: On the Accountability of States to Foreign Stakeholders', AJIL 107 (2013), 295-333 (296); Anne Peters, 'Global Constitutionalism. The Social Dimension' in: Takao Suami, Anne Peters, Dimitri Vanoverbeke and Mattias Kumm (eds), Global Constitutionalism from European and East Asian Perspectives, (Cambridge: Cambridge University Press 2018), 277-350 (346-350).

56 In more detail below, IV.

57 Expressed by United Nations Deputy Secretary-General Amina Mohammed, 3 August $2020,<$ https://www.un.org $>$.

58 Sykes (n. 2), 648. 
Hardly any country can attain self-sufficiency in the short term. Initiatives based on an inward-looking nationalist perspective are likely to lead to similar responses by other states, which could severely damage the pharmaceutical supply chain. ${ }^{59}$ For instance, export restrictions or bans of medical products may trigger a cascade of nationalist reactions. ${ }^{60}$

Recent tensions between the United Kingdom and the European Union (EU) due to the distribution of vaccines by the pharmaceutical company AstraZeneca underscore the pernicious effects of vaccine nationalism. ${ }^{61}$ When the company announced delays in the original distribution schedule, the European Commission reacted by implementing a mechanism wherein the distribution of vaccines from the EU towards third countries will be subject to previous authorisation. ${ }^{62}$ At stake is the perceived preference given by AstraZeneca to the United Kingdom, since supply to the latter has allegedly taken place without interruption. Such an episode shows how high-income economies may compete against one another for earlier access to the vaccine, leading to a potential cascade of nationalist reactions based on a "me-first"logic. ${ }^{63}$

Moreover, there are considerations of solidarity that lie beyond self-interest and aim at fostering cooperation. ${ }^{64}$ Normative claims have emerged on the need for national decision-makers to take into account the needs of persons in other states, as an extension of the obligation to respect, protect and fulfil human rights beyond their territories. ${ }^{65}$ Countries should pay heed to the potentially catastrophic consequences of leaving countries, or even entire regions, last in the supply chain. The protracted distribution of anti-

59 Sykes (n. 2), 648.

60 United Nations Committee on Economic, Social and Cultural Rights, General Comment No. 14: The Right to the Highest Attainable Standard of Health (Art. 12 ICESCR), 2 May 2016, UN Doc. E/C.12/GC/22, para. 41; John Tobin, The Right to Health in International Law (Oxford: Oxford University Press, 2012), 333.

61 Benjamin Mueller and Matina Stevis-Gridneff, 'E.U. and U.K. Fighting Over Scarce Vaccines', The New York Times, 29 January 2021, <https://www.nytimes.com>.

62 Commission Implementing Regulation 2021/111/EU, 29 January, 2021, <https://eurlex.europa.eu>.

63 Arguments held previously in Armin von Bogdandy and Pedro A. Villarreal, 'The EU's and UK's Self-Defeating Vaccine Nationalism', Verfassungsblog, 30 January 2021, <https:// verfassungsblog.de>.

64 Peter West-Oram and Alena Buyx, 'Global Health Solidarity', Public Health Ethics 10 (2017), 212-224 (217-219); Volnei Garrafa, 'Solidarity and Cooperation' in: Henk ten Have and Bert Gordijn (eds), Handbook of Global Bioethics (Pittsburgh/Dublin, Springer, 2014), 169-186 (184-185).

65 Peters (n. 55), 329; Francesca Romanin Jacur, 'Diritto internazionale e risposta alla pandemia da Covid-19' in: Marco Frigessi di Rattalma (ed.), La pandemia da COVID-19. Profili di diritto nazionale, dell'Unione Europea ed internazionale (Turin: G. Giappichelli Editore, 2020), 171. 
retroviral medications against HIV/AIDS in the $1990 \mathrm{~s}$ and early $2000 \mathrm{~s}$ was devastating for the African region, the hardest-hit continent. ${ }^{66}$ Avoiding a repeat of this catastrophe should be part and parcel of any responsible decision-making, both at the national and international levels. Consequently, a complete absence of universal solidarity - i. e., full-blown vaccine nationalism - is legally, morally and politically very dubious indeed. This is expressed both by SDG Goal No. 3, by the WHO's Resolution of 19 May 2020, as well as by two resolutions of the United Nations General Assembly. ${ }^{67}$ Supporting the COVAX Initiative would strive towards fulfilling these goals in the context of a devastating pandemic.

\section{The Set-up and Operation of COVAX}

The COVAX Initiative is spearheaded, among others, by the WHO, 68 which has a long history in fighting communicable diseases. One of its greatest achievements was the fight against smallpox, which was finally eradicated, after decades of vaccination campaigns, in 1979.69 At the moment of writing, another disease, polio, approaches the point of eradication, also thanks to an effort mostly coordinated by the WHO. ${ }^{70}$ Both diseases had a mostly human reservoir - unlike SARS-CoV-2, which seems to have a zoonotic i. e. animalto-person origin..$^{71}$

66 Ellen t'Hoen, 'TRIPS, Pharmaceutical Patents, and Access to Essential Medicines: A Long Way From Seattle to Doha', Chi. J. Int'l L. 3 (2002), 27-46 (27-28); Bradly Condon and Tapen Sinha, Global Lessons from the AIDS Pandemic. Economic, Financial, Legal and Political Implications (Berlin-Heidelberg: Springer, 2008), 30; Frederick Abbott, 'Health and Intellectual Property Rights' in: Gian Luca Burci and Brigit Toebes (eds), Research Handbook on Global Health Law (Cheltenham: Edward Elgar Publishing, 2018), 135-163 (162).

67 UNGA Res. 70/270 of 2 April 2020, A/RES/74/270; and UNGA Res. 74/274 of 20 April 2020, A/RES/74/274.

68 For the role of the WHO in the current pandemic so far, see José Alvarez, 'The WHO in the Age of the Coronavirus', AJIL 114 (2020), 578-587; Eyal Benvenisti, 'The WHO - Destined to Fail? Political Cooperation and the COVID-19 Pandemic', AJIL 114 (2020), 588-597; Armin von Bogdandy and Pedro Villarreal, 'Critical Features of International Authority in Pandemic Response: The WHO in the COVID-19 Crisis, Human Rights and the Changing World Order', Max Planck Institute for Comparative Public Law \& International Law (MPIL) Research Paper No. 2020-18, <https://papers.ssrn.com/sol3/papers.cfm?abstract_id=3600058>.

69 WHO, The Global Eradication of Smallpox. Final Report of the Global Commission for the Certification of Smallpox Eradication (Geneva, 1980).

70 Donald Henderson, 'Principles and Lessons from the Smallpox Eradication Programme', Bulletin of the World Health Organization 65 (1987), 535-546.

71 Kristian Andersen, Andrew Rambaut, W. Ian Lipkin, Edward C. Holmes and Robert F. Garry, 'The Proximal Origin of SARS-CoV-2', Nature Medicine 26 (2020), 450-455. 
In general, international organisations are crucial fora as well as actors when it comes to issues of global solidarity. Their goal is not to replace but to guide and supplement national authorities in their own roles. ${ }^{72}$ They carry the same responsibility towards all persons falling under their membership and are exclusively committed to international community interests such as global health. ${ }^{73}$ Under normative as well as functionalist considerations, ${ }^{74}$ they play a core role amidst the COVID-19 pandemic. Even if binding international obligations on sharing vaccines might be elusive for now, international institutions can orchestrate solutions geared towards the interests of all human beings, i. e., in the light of global solidarity. ${ }^{75}$ In doing so, they can counter the most damaging instances of vaccine nationalism.

In recognition of a need for global solidarity, multiple international institutions and non-state actors participate in the COVAX Initiative. ${ }^{76}$ It gathers financial and legal resources for the distribution of the vaccine across participating countries. The COVAX Initiative offers a glimpse at the potential of global governance for providing solutions to what are literally global problems - such as vaccination against a pandemic disease.

\section{The Institutional Setup}

COVAX is neither an organisation nor an agreement. It represents the common thrust of a series of joint activities to provide vaccines that are then used to immunise the world population against COVID-19. The participants in the COVAX Initiative are, first, international organisations, particularly the WHO, the World Bank and the United Nations Children's Fund (UNICEF). ${ }^{77}$ It stems from the Access to COVID-19 Tools (ACT) Accel-

72 An assessment already linked to other crises in Armin von Bogdandy, Matthias Goldmann and Ingo Venzke, 'From Public International to International Public Law: Translating World Public Opinion into International Public Authority', EJIL 28 (2017), 115-145 (145).

73 On a legal understanding of what are community interests, Rüdiger Wolfrum, 'Identifying Community Interests in International Law: Whose Interests Are They and How Should We Best Identify Them?' in: Eyal Benvenisti, Georg Nolte and Keren Yalin-Mor (eds), Community Interests Across International Law (Oxford: Oxford University Press 2018), 22.

74 Jan Klabbers, 'The EJIL Foreword: The Transformation of International Organizations Law', EJIL 26 (2015), 9-82 (15-19).

75 Kenneth Abbott, Philipp Genschel, Duncan Snidal and Bernhard Zangl, 'Orchestration: Global Governance Through Intermediaries' in: Kenneth Abbott, Philipp Genschel, Duncan Snidal and Bernhard Zangl (eds), International Organizations as Orchestrators (Cambridge: Cambridge University Press 2015), 10-11.

76 The explanation of the mechanism is found at $<$ https://www.gavi.org $>$.

77 UNICEF's participation is explained by its expertise in routine and large scale childhood immunisations. 'Briefing Covid-19 vaccines', The Economist, 14 November 2020. 
erator, a framework of collaboration which is not a new institution either, but rather an informal structure gathering several partners. ${ }^{78}$ COVAX was launched on 3 June as the "vaccines pillar" of the ACT Accelerator, which covers other resources such as diagnostics, therapeutics and health system strengthening. ${ }^{79}$

States make up the second group participating in the initiative. Their number currently amounts to 186, including the United States under the Biden administration as well as China - though not Russia. Participating states are divided into two categories in light of who pays for the vaccines they receive via COVAX. First, there are self-financing states who will pay by themselves for the doses they will receive via the Initiative. They are required to effectuate upfront payments, which helps the Initiative order a higher volume of vaccines, thereby making it more attractive for pharmaceutical companies to join. For high-income countries, COVAX certainly represents a vehicle for their global solidarity, but also for their national interest. Since it was not known which vaccine candidates will ultimately receive regulatory approval, nor what their price would be, self-financing states increased their chances by participating in COVAX, considering its big portfolio of potential vaccines.

The second category is composed of funded states, whose doses will be paid by the World Bank and other donors, in particular the Bill and Melinda Gates Foundation. Funded states qualify for such a category on the basis of the criteria for official development assistance (ODA), as formulated by the World Bank's International Development Association (IDA). Consequently, these countries must have a per capita Gross National Income of under U.S. $\$ 4,000$ per year. ${ }^{80}$ This certainly begs the question of whether this binary threshold is sufficiently nuanced, since self-financing states that score only slightly higher than U.S. $\$ 4,000$ are subjected to the same conditions as highincome states. The current list of self-financing states, for instance, encompasses countries as diverse as Japan and Paraguay. ${ }^{81}$

To participate, self-financing states must conclude an agreement of participation with a public-private partnership under the denomination of Gavi, the Vaccines Alliance (Gavi). ${ }^{82}$ These agreements are contracts under English

78 WHO, What is the ACT-Accelerator, <https://www.who.int>.

79 See also Mark Eccleston-Turner and Harry Upton, 'International Collaboration to Ensure Equitable Access to Vaccines for COVID-19: The ACT-Accelerator and the COVAX Facility', The Milbank Quarterly (forthcoming).

$80<$ https://www.expresspharma.in>.

81 COVAX - List of Participating Economies, 15 December 2020, <https://www.gavi.org>.

82 The acronym Gavi results from its former name, "Global Alliance for Vaccines and Immunization”. 
private law. ${ }^{83}$ For that reason, states are acting here as commercial entities, ${ }^{84}$ in which capacity self-financing states commit themselves to effectuate an initial payment by a certain deadline. ${ }^{85}$

A third group of participants in the COVAX Initiative are non-state actors, first of all the aforementioned Gavi. It is a public-private partnership between international institutions (the WHO, the World Bank and UNICEF) as well as private non-profit associations, of which the Bill and Melinda Gates Foundation is the most prominent example. Gavi is constituted as a foundation under Swiss law. However, it has received privileges and immunities comparable to those granted to an intergovernmental organisation through a "host agreement" with the Swiss government. ${ }^{86}$ Decision-making in Gavi occurs mainly through its Board, which currently comprises twenty-eight members. They include officials of the WHO, the World Bank and UNICEF, a representative of the Bill and Melinda Gates Foundation and of donating states, a number of high-profile individuals selected on the basis of geographic diversity and expertise and, finally, representatives of the vaccine industry. ${ }^{87}$

Another important participating private institution alongside Gavi is the Coalition for Epidemic Preparedness Innovations (CEPI), a Norwegian nonprofit association. Its prominent institutional role becomes apparent in the fact that Gavi and CEPI are chairs of COVAX's own main decision-making body, the COVAX Coordination Meeting (CCM). 88

The distinction between self-financing and funded countries is also embedded in COVAX's internal governance structure. States that pay for themselves are part of the COVAX Shareholders Council. ${ }^{89}$ The other states are part of the Advance Market Commitments Engagement Group, in line with their legal status as recipients of official development assistance. ${ }^{90}$ Through

$83<$ https://www.gavi.org $>$.

84 Veijo Heiskanen, 'State as a Private: the Participation of States in International Commercial Arbitration', TDM 1 (2010), <https://www.transnational-dispute-management.com>.

85 See the model agreements at $<$ https://www.gavi.org $>$.

86 Federal Department of Foreign Affairs of Switzerland, 'The Federal Council concludes a Host Country Agreement with the GAVI Alliance', 23 June 2009, <https://www.admin.ch>; Eelco Szabó, 'Gavi, the Vaccine Alliance. A Unique Case Study in Partnership', IOLR 13 (2016), 149-170; Markus Kaltenborn and Nina-Annette Reit-Born, 'Public Private Partnerships als Akteure des globalen Gesundheitsrechts', AVR 57 (2019), 53-82 (63-64).

$87<$ https://www.gavi.org $>$.

88 COVAX: The Vaccines Pillar of the Access to COVID-19 Tools (ACT) Accelerator. Structures and Principles, 9 November 2020, 6.

89 COVAX Facility Shareholders Council - Terms of Reference, September 2020, <https:// www.gavi.org $>$.

90 COVAX AMC Stakeholders Group - Terms of Reference, September 2020, <https:// www.gavi.org>. 
these two governance bodies, participating countries provide input on the actual operation of COVAX, as well as matters pertaining to their own groups. However, both bodies only have an advisory nature. Actual decisionmaking lies with Gavi and CEPI, with the former having the lead. ${ }^{91}$

Last but certainly not least, representatives of the pharmaceutical sector participate in the COVAX Initiative. They are selected by the International Federation of Pharmaceutical Manufacturers \& Associations and the Developing Countries Vaccine Manufacturers Network. Participation by the private corporate sector is deemed to be a boon, as the perspective of potential manufacturers gives first-hand insights on what the actual capacity to produce and distribute the vaccine against COVID-19 really is; otherwise, the calculations would have run the risk of being based on wishful thinking. Though it raises questions of potential conflicts of interest in the governance of COVAX, these for-profit actors do not have any decision-making power. Their inclusion is meant to bring operational input into the discussions.

At the very heart of the COVAX Initiative sits the so-called COVAX Facility. It consists of a network of legal agreements under English law. It represents the very mechanism for procuring, financing and distributing vaccines. Its legal administrator is Gavi, ${ }^{92}$ which is thereby responsible for the COVAX Facility's operations.

This public-private partnership is innovative and very much in the logic of global governance. ${ }^{93}$ As such, its hybrid public-private nature represents a strategic advantage, but also poses risks. It allows using the legitimacy, knowhow and instruments of international organisations, which are bound and committed by their mandates. At the same time, it incorporates the flexibility of private actors and private-law instruments. It seems that private law-based contracts allow to better address complex issues of legal liability for eventual risks related to vaccines. However, the private-law form carries the risk of opacity with regard to the terms negotiated with the pharmaceutical companies. ${ }^{94}$ Moreover, there are concerns of accountability, since it is not clear how Gavi decides and to whom it responds beyond its own governing

91 Supra (n. 88).

92 Supra (n. 88), 13.

93 Gian Luca Burci, 'Public/Private Partnerships in the Public Health Sector', Int'l Org. L. Rev 359 (2009), 380; Kaltenborn and Reit-Born (n. 86), 53-82; Mateja Steinbrück-Platise, 'The Changing Structure of Global Health Governance' in: Leonie Vierck, Pedro Villarreal and Katarina Weilert (eds), The Governance of Disease Outbreaks. International Health Law: Lessons from the Ebola Crisis and Beyond (Baden-Baden: Nomos 2017), 83-112 (84).

94 Already criticised by the NGO Médecins Sans Frontières in a preceding model of Advance Market Commitments designed by the Gavi Alliance. Médecins Sans Frontières, Analysis and Critique of the Advance Market Commitment (AMC) for Pneumococal Conjugate Vaccines (PCVs) and Impact on Access, MSF Briefing Document (June 2020), 2. 
board. ${ }^{95}$ In particular, the active role of private for-profit actors has been a source of criticism..$^{96} \mathrm{~A}$ similar setting of potential conflicts of interest was present in past pandemics, such as H1N1 influenza in 2009, where pharmaceutical companies attained a considerable profit. ${ }^{97}$

\section{The Structure of Commitments}

As mentioned above, the COVAX Facility is a network of legal agreements. Its first operative dimension for the global distribution of vaccines consists of contracts for securing access to them, similar to the APAs discussed in section II.2. As Gavi is the legal administrator of COVAX, it will be the main actor signing most of the necessary agreements with both the suppliers and the purchasers. The other parties include states individually and pharmaceutical companies that are currently developing "vaccine candidates". ${ }^{98}$

There are three different types of agreements in the COVAX Facility. First are those with pharmaceutical companies known as Advance Purchase Commitments. Here, vaccine manufacturers accept a fixed price for all purchasers through COVAX's legal representative, Gavi, and guarantee priority access. ${ }^{99}$ Through separate investment agreements, CEPI may give financial support for research and regulatory approval costs. ${ }^{100}$ At the moment of writing, the most recent forecast by the COVAX Facility indicates the initial target of distributing 2 billion doses by the end of 2021 may be met, subject to a series of evolving circumstances like manufacturing capacity, regulatory approval and national-level logistics of receiving countries. ${ }^{101}$

The second operative dimension is the eventual distribution of the vaccine to all participating states. In that sense, COVAX sits at the heart of the global

95 Burci (n. 93), 371-372.

96 Katerini Storeng, 'The GAVI Alliance and the "Gates Approach" to Health System Strengthening', Global Public Health 9 (2014), 865-879.

97 Parliamentary Assembly, Council of Europe, 'Handling of the H1N1 pandemic: more transparency needed', Resolution 1749 (2010), para. 2; Anne Peters, 'Managing Conflict of Interest: Lessons from Multiple Disciplines and Settings' in: Anne Peters and Lukas Nadschin (eds), Conflict of Interest in Global, Public and Corporate Governance (Cambridge: Cambridge University Press, 2012), 409-411.

98 COVAX Facility Explainer. Participation Arrangements for Self-Financing Economies (2020), 2.

99 COVAX Facility, Terms and Conditions for Self-Financing Participants, Term No. 5.

$100<$ https://www.gavi.org $>$.

101 CEPI/Gavi/WHO, COVAX Global Supply Forecast. 20 January 2021, <https:// www.gavi.org>. 
distribution for the vaccines it secures. With self-financing states, Gavi will use the contractual model of so-called Commitment Agreements, similar to the above-mentioned Advance Purchase Commitments. ${ }^{102}$ Conversely, for funded states the vaccine will be supplied through the so-called Advance Market Commitments. ${ }^{103}$ This distribution will be effectuated through the instruments of official development assistance. Despite their different denomination, all of these agreements are derivatives of APAs, since they entail commitments by the parties regarding vaccines initially subjected to uncertainty regarding their successful approval.

To apply, funded states need to submit a "vaccine request form" to Gavi. 104 They are required to accept the "Gavi Grant Terms and Conditions", 105 which shield Gavi, its other COVAX partners as well as donors against multiple instances of legal liability. They must also sign indemnification agreements with the vaccine manufacturers. Similarly, funded states must accept to reimburse Gavi in case the donated vaccines are used for purposes other than those stated in COVAX, e. g. for re-selling them to third parties. ${ }^{106}$

The agreements described above are subject to commercial arbitration under the United Nations Commission of International Trade Law (UNCITRAL) Arbitration Rules. In case there are disputes due to e.g. failure by self-financing states to pay for their doses in the specified time or if financed states resale the vaccine to other countries, all agreements above designate Switzerland as seat of potential dispute settlement. This should give teeth to the obligations related to COVAX's global distribution of vaccines against COVID-19.

\section{The Allocation of Vaccines}

The COVAX Facility will distribute vaccines according to a blueprint developed by the WHO called "fair allocation framework". ${ }^{107}$ All participating states will have access to the vaccines procured by COVAX at the same

102 COVAX, Explanatory note: Legal agreements with COVAX Facility Self-Financing Participants, <https://www.gavi.org $>$.

103 The GAVI COVAX AMC: An Investment Opportunity (2020), 4; see also <https:// www.gavi.org $>$.

104 COVAX AMC Vaccine Request - Terms \& Conditions and Application Form, $<$ https://www.gavi.org>.

105 COVAX AMC Vaccine Request (n. 104).

106 COVAX AMC Vaccine Request (n. 104).

107 WHO, Fair allocation mechanism for COVID-19 vaccines through the COVAX Facility (2020). 
time as well as proportionally, since the goal is to strive towards sufficient doses for $20 \%$ of every state's population - which is currently projected to occur at the end of $2021 .{ }^{108}$ The $20 \%$ is not calculated randomly, but reflects the outcome of the WHO's approximate assessment of the amounts needed across countries for protecting at-risk groups. ${ }^{109}$ The receiving states must prioritise healthcare workers and risk groups. Consequently, the initial phase of distribution under COVAX is designed in an egalitarian fashion, though only for those vaccines acquired through its Facility.

Indeed, the Initiative foresees the possibility for participating states to also obtain vaccines for which they already have an APA, such as in the case of the EU. The COVAX Initiative recognises the fact that countries may separately secure early access to vaccines through parallel bilateral APAs. Such deals do not affect a participating state's access to doses through COVAX itself. ${ }^{110}$ Countries with a sufficient financial capacity are bound to look for multiple means to secure such a coveted resource. Accordingly, the populations of richer countries are likely to be better served.

In terms of allocation under COVAX, self-financing states may purchase doses for a maximum of $50 \%$ of those required for their populations, but they will not receive more than $20 \%$ until all other states have received as much. There is, however, no clear indication on how global distribution will take place after this initial threshold of $20 \%$ has been met, i. e., whether the countries purchasing up to $50 \%$ will have priority in the later stages over funded states.

There is also the possibility for self-financing states to purchase even less than $20 \%$. This is not as strange as it looks at first sight. For one, given the price tag for the vaccines, it may be that states are actually not willing to pay them through COVAX on the due dates. In the end, the separate commitments through their own APAs might be more attractive. ${ }^{111}$ For that reason, the COVAX agreements require self-financing states to purchase via COVAX at least $10 \%$ of their needs.

The COVAX Initiative establishes a fixed-price system for doses, although the final price will be determined once the manufacturers, following regulatory approval of the vaccine, have fully calculated production costs. The objective is to prevent participating states, especially self-financing ones, and companies from engaging in subsequent bilateral negotiations, using the price of vaccine doses as leverage for preferential treatment. Therefore, COVAX

\footnotetext{
$108<$ https://www.gavi.org $>$.

109 WHO (n. 107).

110 COVAX Facility. Terms and Conditions for Self-Financing Participants, 16.

111 COVAX, Commitment agreements, 29 October 2020.
} 
was initially envisaged not only for low and lower-middle income countries, but rather as a multilateral alternative to the bilateral APAs between individual states and pharmaceutical companies.

The COVAX Initiative is perhaps the only opportunity for many lowand lower-middle income countries to gain access to promising vaccines at the early stages of their distribution. They will receive doses up to $20 \%$ of their population on the basis of official development assistance, meaning they will not be required to undertake an upfront payment for those doses. The financial cost of their participation in COVAX will be covered by international organisations, like the World Bank, or by philanthropic institutions, notably the Bill and Melinda Gates Foundation.

\section{COVAX and Human Rights}

In the following section, the article shows that COVAX fleshes out general guidelines that international law provides for tackling the COVID-19 pandemic. As international law continues to be state-centred, it recognises the special responsibility of governments towards individuals from their countries' population (IV.1). At the same time, ideas of an international community of states, of an international community tout court and even of international solidarity have left the realm of purely normative projections and are enshrined in international obligations, particularly in human rights. They materialise in the no harm principle (IV. 2) and the duty to international assistance (IV.3). These general norms come together in the international right to health.

\section{The Domestic Preference in the International Right to Health}

The issue of a fair and equitable distribution of vaccines among several countries raises many difficult questions. ${ }^{112}$ The following analysis addresses some of those in light of the right to health. The core provision at the international level is Article 12 of the ICESCR. Most pertinent is Article 12.3(c),

112 For a bioethics perspective, see Ezekiel Emanuel et al., 'Fair Allocation of Scarce Medical Resources in the Time of Covid-19', 382 The New England Journal of Medicine (2020), 2049-2055. For a more general analysis of the WHO's Fair Allocation Scheme and vaccine nationalism, Ezekiel Emanuel et al., 'An ethical framework for global vaccine allocation', Science 369 (2020), 1309-1312. 
which obliges states to take the necessary steps for " $[\mathrm{t}]$ he prevention, treatment and control of epidemic [...] and other diseases". The Committee of Economic, Social and Cultural Rights, under its mandate to provide an interpretation of the Covenant's obligations, ${ }^{113}$ has concluded in its General Comment 14 that immunisation is a component of states' obligations to protect individuals against epidemic diseases. ${ }^{114}$ It also considers securing the necessary pharmaceutical products, including vaccines, to be part of the element of "availability", which covers the three levels of "respect, protect and fulfil" as obligations under the right to health. ${ }^{115}$

This is consistent with the general doctrinal understanding. A state's obligations under the right to health have been mostly interpreted as primarily owed to individuals from their own population. ${ }^{116}$ The nature of existing political and constitutional systems support this interpretation: national (or, in the case of the European Union, supranational) authorities must respond and are directly accountable to their own population. ${ }^{117}$ Powerful mechanisms, not just legal ones, stand ready rising from this responsibility: If national authorities do not take convincing steps, they risk eliciting the wrath of their population. That is the basic logic of national political accountability. ${ }^{118}$ This also applies to the European Union, whose constituency comprises European citizens and which has "to promote the well-being of its peoples". ${ }^{119}$ The European Commission used this argument to justify its bilateral APAs with pharmaceutical companies. ${ }^{120}$

Up to this point, one could be tempted to conclude that the international right to health calls for vaccine nationalism. That, however, would overlook the transnational dimension of the right to health. Such a dimension has two elements: the no harm principle and the duty of assistance and cooperation.

113 Constituted by ECOSOC Resolution 1985/17 of 28 May 1985.

114 General Comment 14 (n. 60), para. 44.

115 Eibe Riedel, 'The Right to Health under the ICESCR. Existing Scope, New Challenges and How to Deal with It' in: Andreas von Arnauld, Kerstin von der Decken and Mart Susi (eds), The Cambridge Handbook of New Human Rights. Recognition, Novelty, Rhetoric (Cambridge: Cambridge University Press 2020), 107-123 (113).

116 Martin Buijsen, 'The Meaning of "Justice" and "Solidarity" in Health Care' in: André den Exter (ed.), International Health Law. Solidarity and Justice in Health Care (Apeldoorn: Maklu, 2008), 55.

117 Sykes (n. 2), 651.

118 Peters (n. 55), 328.

119 Article 3 para. 1 Treaty on European Union.

$120<$ https://ec.europa.eu>. 


\section{The No Harm Principle}

As a general background, the no harm principle is part and parcel of states' general international law obligations. ${ }^{121}$ The principle was first affirmed within the aegis of cross-border environmental damages in the landmark Trail Smelter dispute, by means of an obligation for states not to allow activities within their territory, even by private actors, that may cause harm to another state. ${ }^{122}$ The principle has expanded onto multiple regimes of public international law, notably as a cornerstone of international environmental law. ${ }^{123}$ Ongoing debates point towards a shift from a "negative" approach focused on refraining from causing harm, towards a "positive" one of actually taking steps to prevent it. ${ }^{124}$

There is a broad consensus that the international right to health incorporates the no harm principle, especially in its "negative" dimension. Under Article 12 of the ICESCR, there is an obligation for states not to harm the health of individuals in other countries. ${ }^{125}$ Such reasoning could be applied to national stockpiling of vaccines against COVID-19 beyond what is immediately necessary for their own population. The combination of scarcity as well as a timepressure to gain access to such vaccines makes hoarding particularly damaging for other countries' chances of access. Though there are no international limits to the number of vaccines that may be purchased, a legal threshold could consist of when that number surpasses the number needed to protect their population.

The normative criteria for estimating when a country is actually hoarding is uncertain. Some commentators posit that hoarding would start when more doses are kept than those needed for maintaining the virus' rate of transmission $(\mathrm{Rt})$ below a value of $1 .{ }^{126}$ Retaining more thereby hinders the enjoyment of the right to health of the population of other countries, particularly

121 Jelena Bäumler, Das Schädigungsverbot im Völkerrecht. Eine Untersuchung anhand des Umwelt-, Welthandels- und Finanzvölkerrechts (Berlin-Heidelberg: Springer 2017), 288-289.

122 Trail Smelter Case (United States v. Canada), Award of 16 April 1938 and 11 March 1941, 3 UNRIAA (1941), 1965; Russell A. Miller, 'Trail Smelter Arbitration' in: Rüdiger Wolfrum (ed.), MPEPIL (online edn., Oxford: Oxford University Press 2007).

123 Jaye Ellis, 'Has International Law Outgrown Trail Smelter?' in: Eirik Bjorge and Cameron Miles (eds), Landmark Cases in Public International Law (Oxford/Portland: Hart Publishing 2017), 56-65.

124 Jutta Brunnée, Procedure and Substance in International Environmental Law?, RdC 405 (2020), 87-240 (158).

125 Brigit Toebes, The Right to Health as a Human Right in International Law (Antwerp/ Groningen/Oxford: Hart/Intersentia, 1999), 321-326; Eszter Kollar, Sebastian Laukötter and Alena Buyx, 'Humanity and Justice in Global Health: Problems with Venkatapuram's Justification of the Global Health Duty', Bioethics 30 (2016), 41, at 47; for a thorough legal reconstruction, Bäumler (n. 121).

126 Ezekiel Emanuel et al. (n. 112), 1309. 
those belonging to high-risk groups. ${ }^{127}$ Another view, incorporated in COVAX's vaccine allocation framework, considers that states should initially selfrestraint their vaccine procurement after reaching approximately the equivalent of $20 \%$ of their population, at least until other countries have had an opportunity to gain access. ${ }^{128}$ In past events, such as the H1N1 pandemic, the distorting effects of stockpiling for fair and equitable global distribution were in open view. ${ }^{129}$ The reasoning in that respect is likely to be parallel to that with respect to Articles XI:2 and XX(b) GATT.130

However, it will be hard to substantiate any violation, as this requires information that is hard to obtain. ${ }^{131}$ The obvious way to know how many vaccines are being purchased is by looking at numbers related to the APAs signed so far. But these contracts are generally not disclosed to the public, as they are classified as "trade secrets" or "business confidential/sensitive information". ${ }^{132}$ There are no international legal tools to require transparency. Instead, both pharmaceutical companies and the procuring states need to agree to disclose their APAs, with the necessary redacted clauses. Even in instances where the APAs have been published, issues such as the exact amount of purchased vaccines and, notably, the price per unit, are usually not disclosed..$^{133}$

The United Nations Committee on Economic, Social and Cultural Rights (CESCR) issued a statement on November, 2020, regarding global access to the vaccine against COVID-19. The Committee criticised the proliferation of bilateral contracts between pharmaceutical companies and high-income economies. Due to the normally secretive nature of these contracts, the full extent of the hoarding itself is known only through secondary, i.e. indirect references. ${ }^{134}$ Officially revealing these figures would go a long way toward identifying the states that engage in the sort of vaccine nationalism that violates Article 12.3(c) ICESCR. ${ }^{135}$

127 On the need to prioritise high-risk groups, see also Inter-American Commission of Human Rights, Pandemic and Human Rights in the Americas, Resolution 1/20 (Adopted by the IACHR on April 10, 2020).

128 Supra (n. 108).

129 Turner (n. 35).

130 See supra, part II. 3.

131 Thoroughly addressed in Wirtz et al. (n. 12).

132 Wirtz et al. (n. 12), 424.

133 See two publicly available redacted APAs signed by the European Commission, on one hand, and two pharmaceutical manufacturers, on the other hand: with AstraZeneca and with CureVac (<https://ec.europa.eu>).

134 See the updated list by Bloomberg, <https://www.bloomberg.com>.

135 For a normative argument for transparency in the pharmaceutical sector, see Ulrich Gassner, 'Transparenz als regulatives Prinzip im Arzneimittelsektor' in: Hartmut Bauer, Detlef Czybulka, Wolfgang Kahl and Andreas Vosskuhle (eds), Wirtschaft im offenen Verfassungsstaat (Munich: Verlag C. H. Beck, 2006), 61-74 (62-63). 
Conversely, COVAX's model legal agreements provide more transparency than bilateral APAs. To begin with, the COVAX Facility's template legal agreements for self-financing states are publicly accessible. ${ }^{136}$ Thus, unlike bilateral APAs, COVAX provides all participants the certainty that no state is securing better terms and conditions with pharmaceutical companies. Moreover, the terms and conditions of COVAX's legal agreements require states to disclose their existing bilateral APAs with pharmaceutical companies. ${ }^{137}$

Not all of COVAX's operations are accessible to the public. Agreements between pharmaceutical companies and Gavi, similar to bilateral APAs with individual states, are so far not public. Nevertheless, the template agreements between Gavi and self-financing states allows other states to ascertain that there is no preferential treatment depending on purchasing power. It helps to ensure that vaccine hoarding does not take place through COVAX. ${ }^{138}$ Since joining the initiative is legally voluntary, it does provide for a considerable incentive for preventing self-defeating competition between states.

\section{The Duty of International Assistance}

The second transnational element of the right to health consists in the duty to provide for international assistance and cooperation, as enshrined in Article 2(1) ICESCR. ${ }^{139}$ If that is accepted in principle, the question remains how this assistance and cooperation ought to take place during an acute and global health emergency, and to what extent is requires sharing essential resources.

General Comment 14 offers an initial formulation of states' obligations to respect, protect and fulfil "the enjoyment of the right to health in other countries", depending on how many resources they are able to deploy for such purpose. ${ }^{140}$ It is linked to a principle of common but differentiated responsibilities, where states share the burden in accordance with their capacities. ${ }^{141}$ Here, the core question of availability of resources comes to the

136 Supra (n. 102).

137 Supra (n. 99), 16.

138 Bogdandy and Villarreal (n. 63).

139 Committee on Economic, Social and Cultural Rights, General Comment 3: The Nature of States Parties' Obligations (Art. 2(1) ICESCR), 14 December 1990, E/1991/23, para. 13; General Comment 14 (n. 60), para. 45; see also Tobin (n. 60), 333.

140 General Comment 14 (n. 60), para. 39.

141 Olivier De Schutter, Asbjørn Eide, Ashfaq Khalfan, Marcos Orellana, Margot Salomon and Ian Seiderman, 'Commentary to the Maastricht Principles on Extraterritorial Obligations of States in the Area of Economic, Social and Cultural Rights', HRQ 34 (2012), 1084-1169 (1149-1150). 
fore, ${ }^{142}$ especially amidst situations of global scarcity of a medical product such as the COVID-19 vaccines. Further refining the latter point, the Maastricht Principles on Extra-Territorial Obligations of States in the Area of Economic, Social and Cultural Rights (Maastricht Principles) provide an important attempt to substantiate extraterritorial duties. ${ }^{143}$ They underscore the obligation of every state to realise such rights "to the maximum of its ability", while at the same time distinguishing the obligations owed to the population of other states. ${ }^{144}$ They point towards the need for states to cooperate in "the universal fulfilment of economic, social and cultural rights". ${ }^{145}$ What the Maastricht Principles do not address, however, are situations of global supply shortage, where all states are in dire need of the same resource. Commentators on these Principles have stressed that states' extraterritorial obligations do not entail the duty to realise the ESC rights of persons everywhere. ${ }^{146}$

It is undisputed that territorial and extraterritorial obligations differ. It is largely agreed, for instance, that global solidarity cannot merely be an international projection of the understanding of solidarity in national settings. ${ }^{147}$ This is particularly true for rights-based approaches to healthcare systems that promote universal medical services on the basis of need and not ability to pay. ${ }^{148}$ Indeed, such reasoning informs a statement by the Committee on Economic, Social and Cultural Rights of 15 November, 2020, which emphasises states' obligations to contribute to the health of persons beyond their territory..$^{149}$

142 Elif Askin, 'Extraterritorial Human Rights Obligations of States in the Event of Disease Outbreaks' in: Leonie Vierck, Pedro A. Villarreal and Katarina Weilert (eds), The Governance of Disease Outbreaks. International Health Law: Lessons from the Ebola Crisis and Beyond (Baden-Baden: Nomos 2017), 175-211 (210-211).

143 Developed by Maastricht University and the International Commission of Jurists on 28 September 2011, available at <https://www.etoconsortium.org $>$.

144 Principles 4 and 31, Maastricht Principles.

145 Principle 30, Maastricht Principles.

146 De Schutter, Eide, Khalfan, Orellana, Salomon and Seiderman (n. 141), 1097, 1151.

147 Jürgen Habermas, 'Solidarität jenseits des Nationalstaats. Notizen zu einer Diskussion' in: Jens Beckert, Julia Eckert, Martin Kohli und Wolfgang Streeck (eds), Transnationale Solidarität. Chancen und Grenzen (Frankfurt a. M.: Campus, 2004), 225-235 (226).

148 Colleen Flood and Aeyal Gross, 'Conclusion: Contexts for the Promise and Peril of the Right to Health' in: Colleen Flood and Aeyal Gross, The Right to Health at the Public/Private Divide (Cambridge: Cambridge University Press, 2014), 452; Alicia Ely Yamin, 'Taking the Right to Health Seriously: Implications for Health Systems, Courts, and Achieving Universal Health Coverage', HRQ 39 (2017) 341-368 (351-356).

149 Committee on Economic, Social and Cultural Rights, Statement on universal and equitable access to vaccines for the coronavirus disease (COVID-19), E/C.12/2020/2, 15 December 2020, paras 11-12, <https://tbinternet.ohchr.org>. 
To fully assess COVAX in light of the international right to health, one also has to look into the possible human rights obligations of the relevant corporations. Traditionally, international human rights only bind states. Today, however, the picture has become far more complex, and blurry. ${ }^{150}$ General Comment 14 considers the responsibilities of private business actors, in particular pharmaceutical companies, for facilitating the realisation of the right to health. ${ }^{151}$ Similarly, the legally non-binding Ruggie Principles enshrine a series of criteria for business enterprises' conduct regarding due diligence in respecting human rights. ${ }^{152}$

Furthermore, since the year 2002, the Human Rights Council has appointed several Rapporteurs on the right to health. ${ }^{153}$ Some reached the conclusion that the intellectual property regime should not prevent a state from providing access to medicines. In his report of 2009, then-Special Rapporteur Paul Hunt even asserted the "shared responsibility" of both states and the private pharmaceutical sector to enhance access to medicines. ${ }^{154}$ Accordingly, there are grounds to argue for some degree of human-rights responsibility of private corporations in the field of health. However, neither the General Comment 14 nor the reports issued by Special Rapporteurs on the Right to Health give guidance on whether a corporation must give preference in their contracts for vaccines to some states rather than to others.

In conclusion, the international right to health stresses the differentiated responsibility of states: While the main responsibility lies with their countries' populations, they also carry some responsibility towards the population of other countries. That leaves much open. Indeed, it would be an overstretch to deduce from the international human right to health specific blueprints for vaccination in a situation of global emergency. At the same time, it is clear that a distributive mechanism like COVAX can be a way by which states discharge their negative and their positive obligations towards populations of other states and live up to their commitments under the Sustainable Development Goals. On a broader normative level, COVAX can be considered as a

150 From a perspective of political science, see Janne Mende, Global Governance und Menschenrechte. Konstellationen zwischen Privatheit und Öffentlichkeit (Baden-Baden: Nomos, 2020), 187.

151 General Comment 14, para. 42.

152 UN Human Rights Council, Report of the Special Representative of the SecretaryGeneral on the issue of human rights and transnational corporations and other business enterprises (John Ruggie), Annex, UN Doc A/HRC/17/31 of 21 March 2011, adopted by Human Rights Council Resolution 17/4, UN Doc A/HRC/RES/17/4 of 6 July 2011.

153 Moon and Hein (n. 21), 52.

154 Report of the Special Rapporteur on the right of everyone to the enjoyment of the highest attainable standard of physical and mental health, A/63/263, 11 August 2008, para. 44. 
forward-looking form of global solidarity that governments can readily explain to their citizens.

\section{Conclusion: COVAX as a Template for Sustainable Solidarity}

In the race for safe and effective vaccination against COVID-19, national authorities rightly strive to serve their countries' populations, as mandated by both national and international law. This, however, does not justify a vaccine nationalism that ruthlessly disregards other populations' health. $\mathrm{Na}-$ tional authorities must realise that the ongoing pandemic concerns the entire globe. Therefore, differentiated schemes of distributive justice are needed. International law provides some substantive criteria for such schemes as well as a plethora of instruments for creating global vehicles of vaccine distribution.

COVAX's initial, more ambitious goals of preventing vaccine nationalism altogether through a multilateral vaccine procurement model have not been accomplished. Bilateral APAs have proliferated and could lead to vaccine hoarding by a few countries. The distribution of the first approved vaccines against COVID-19 began along these lines, with a select number of countries receiving most of the doses. ${ }^{155}$ Nevertheless, COVAX's available template agreements provided a legally feasible multilateral alternative. The transparency in COVAX's agreements between Gavi and participating self-financing states would have prevented self-defeating competition altogether. Hence, at the very least COVAX confirmed that vaccine nationalism in the COVID-19 pandemic was never a foregone conclusion.

In sum, the COVAX Initiative displays the potential of both public international law and private law to provide principles as well as operational tools for the distribution of vaccines against COVID-19. COVAX represents an innovation in enhancing equitable access to a life-saving medication in times of dire need. Its framing of sustainable solidarity balancing competing interests might provide an idea for how to deal with other challenges, such as climate change - perhaps an even more threatening catastrophe than the COVID-19 pandemic, albeit one that happens in slow motion.

155 Supra (n. 134). 